\title{
Case series of papillectomy by endoscopic retrograde cholangiopancreatography (ERCP)
}

\author{
Nader Roushan ${ }^{1}$, Seyed Farshad Allameh*1, Omid Eslami ${ }^{1}$ \\ Received: 12 Dec 2017 \\ Published: 30 May 2018
}

\begin{abstract}
Ampullary neoplasms are one of the causes of obstructive jaundice. Endoscopic retrograde cholangiopancreatography (ERCP) is useful procedure for diagnosing and tissue sampling of ampullary neoplasms. Ampullectomy by resecting entire ampulla provides whole lesion for pathologic evaluation and also is appropriate for real pathologic staging for further management decision but ampullectomy considered as a heroic endoscopic procedure. We share our experience in this field and explain our results.
\end{abstract}

Keywords: Ampullary neoplasm, Endoscopic retrograde cholangiopancreatography

Copyright $\odot$ Iran University of Medical Sciences

Cite this article as: Roushan N, Allameh SF, Eslami O. Case series of papillectomy by endoscopic retrograde cholangiopancreatography (ERCP). Med J Islam Repub Iran. 2018(30 May);32:43. https://doi.org/10.14196/mjiri.32.43

\section{Introduction}

Ampullary neoplasms are common cause of obstructive jaundice. Cross sectional imaging like CT scan has only 20 percent sensitivity for diagnosis of ampullary neoplasms. Endoscopic ultrasonography is useful for diagnosing and staging of ampullary neoplasms but it only has 70 percent accuracy for tissue sampling by FNA. ERCP is a gold standard procedure for diagnosing and tissue sampling of ampullary neoplasms. The endoscopic retrograde cholangiopancreatography (ERCP) is nearly 100 percent accurate when ampulla is grossly tumoral or ulcerated.

Gross appearance of ampulla is normal in 30 percent of ampullary neoplasms and physicians only suspect when it is causing obstructive jaundice or grossly prominent. The usual approach for tissue sampling in these lesions is biopsy after sphincterotomy. Even after sphincterotomy the sensitivity of biopsy is low and do not represent the pathology of entire ampulla and most of the times multiple ERCP and biopsy are required (1).

Ampullectomy by resecting entire ampulla provides whole lesion for pathologic evaluation and also is appropriate for real pathologic staging for further management decision.

As ampullectomy is a heroic endoscopic procedure that gastroenterologists hesitate to perform.

\section{Corresponding author: Dr Seyed Farshad Allameh, allamehfarshad@gmail.com}

1. GI Ward, Imam Khomeini Hospital, Tehran University of Medical Sciences, Tehran, Iran.
Endoscopic papillectomy (EP) is accepted nowadays as an alternative therapy to surgery in ampullary adenoma and has high success and low recurrence rates.

Endoscopic ampullectomy means the resection of the mucosa and submucosa of the duodenal wall, in attachment area of the ampulla of Vater, including the tissue around the bile duct and the pancreatic duct orifices $(2,3)$.

The accepted criteria for Endoscopic ampullectomy include a size up to $5 \mathrm{~cm}$, no evidence of malignancy on endoscopic findings, and no evidence of intraductal growth. These indications are in ongoing progress.

Although the endoscopic ampullectomy is a high-risk procedure, it has successfully replaced surgical intervention for benign or malignant papillary tumors. Moreover, the procedur is associated with lower morbidity and mortality in comparison with surgery and seems to be a preferable treatment option for small ampullary tumors without intraductal extension. When Endoscopic ampullectomy performed by an experienced physician, it can lead to successful eradication of tumor in up to $85 \%$ of patients with ampullary adenomas. Thus, it is an effective and safe modality and should be established as the first line therapy for ampullary adenomas (4-6).

$\uparrow$ What is "already known” in this topic:

Endoscopic papillectomy (EP) is accepted nowadays as an alternative therapy to surgery in ampullary adenoma and has high success and low recurrence rates.

$\rightarrow$ What this article adds:

Here we report the result of initial experience of our center in ampullectomy. 


\begin{tabular}{|c|c|c|c|c|c|}
\hline Age & Sex & Presentation & Endoscopic findings & Pathology & Follow up \\
\hline 63 & Female & Icterus and itching & Prominent ampulla & $\begin{array}{l}\text { Tubular adenoma with focal high-grade } \\
\text { dysplasia }\end{array}$ & $\begin{array}{c}\text { No tumor in control } \\
\text { ERCP }\end{array}$ \\
\hline 69 & Male & $\begin{array}{l}\text { Icterus and itching and } \\
\text { weight loss }\end{array}$ & Prominent ampulla & $\mathrm{R} / \mathrm{O}$ Adenocarcinoma & In follow up \\
\hline 42 & Female & Icterus and itching & Ampullary polyp & $\begin{array}{c}\text { Tubulovillous polyp with low grade } \\
\text { dysplasia }\end{array}$ & $\begin{array}{l}\text { No tumor in control } \\
\text { ERCP }\end{array}$ \\
\hline 50 & Male & Icterus & Prominent ampulla & $\begin{array}{c}\text { Adenocarcinoma arising in tubular } \\
\text { adenoma with invasion to muscularis } \\
\text { propria }\end{array}$ & surgery \\
\hline 58 & Female & Abdominal pain & Prominent ampulla & Chronic duodenitis & $\begin{array}{c}\text { Pancreatitis as a side } \\
\text { effect }\end{array}$ \\
\hline 48 & Male & Icterus & Tumor of ampulla & $\begin{array}{l}\text { Well differentiated neuroendocrine } \\
\text { tumor with invasion to duodenal wall }\end{array}$ & surgery \\
\hline 81 & Female & Abdominal pain & Prominent ampulla & Hyperplastic polyp & Ok \\
\hline 64 & Female & Fever and icterus & Tumor of ampulla & $\begin{array}{l}\text { Tubulovillous adenoma with focal high- } \\
\text { grade dysplasia/T3N1 on EUS }\end{array}$ & In follow up \\
\hline 65 & Female & Icterus and itching & Tumor of ampulla & Poorly differentiated adenocarcinoma & In follow up \\
\hline 55 & Female & $\begin{array}{l}\text { Icterus and itching and } \\
\text { weight loss }\end{array}$ & Tumor of ampulla & R/O Adenocarcinoma & In follow up \\
\hline 79 & Male & $\begin{array}{l}\text { Fever and weight loss and } \\
\text { Icterus }\end{array}$ & Prominent ampulla & Invasive adenocarcinoma & In follow up \\
\hline 70 & Female & Icterus & Prominent ampulla & Well differentiated adenocarcinoma & In follow up \\
\hline 74 & Female & Icterus & Prominent ampulla & $\begin{array}{l}\text { Adenocarcinoma well to moderate dif- } \\
\text { ferentiated }\end{array}$ & In follow up \\
\hline
\end{tabular}

\section{Case series}

Here we report the result of initial experience of our center in an ampullectomy procedure. In our center we have as first report of 13 patients and the main data are summarized in Table 1. Also you can see the ampulla after resection from one patient in Fig. 1.

Our experience in ampullectomy showed that it is a safe and practical approach for diagnosis and also treatment of ampullary neoplasms.

\section{Discussion}

In the case series of Shujiro $\mathrm{T}$ and his colleagues 80.9 percent of patients treated with single session of ampullectomy with various complications such as pancreatitis, cholangitis, retroperitoneal perforation and bleeding (7).

Follow-up with surveillance should be performed

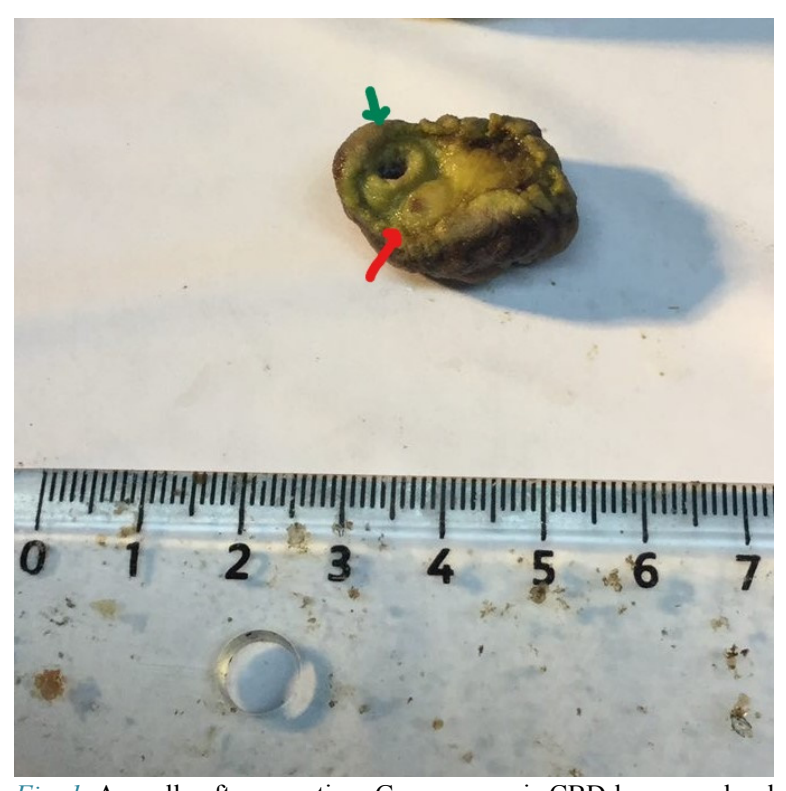

Fig. 1. Ampulla after resection. Green arrow is CBD lumen and red Pancreatic duct

whithin first 4 to 8 weeks after ampullectomy and should be continued for at least three years when the pathology report indicating a high-grade dysplasia. This is because of the possible recurrence of tumor during these years (8).

In other case series Between January 2008 and November 2011, 12 patients with ampullary tumors underwent endoscopic ampullectomy. The technique was endoscopic double-snare for all 12 patients. The ampullectomy of these patients was safe and complete (9-11).

It is standard practice in GI tract to proceed to resect entire lesions like polypoid lesions by simple snare polypectomy or by advance procedures like Endoscopic Mucosal Resection (EMR) or Endoscopic Submucosal Dissection (ESD). We suggest that these approaches also can be useful in ampullary neoplasms because it leads to good diagnostic and curative results with low side effects. The ERCP centers should have good experience with this procedure.

\section{Conflict of Interests}

The authors declare that they have no competing interests.

\section{References}

1. Giovanni D De Palma. Endoscopic papillectomy: Indications, techniques, and results. World J Gastroenterol. 2014 February 14;20(6): $1537-1543$.

2. El Hajj II, Coté GA. Endoscopic diagnosis and management of ampullary lesions. Gastrointest Endosc Clin N Am 2013; 23: 95-109.

3. Baillie J. Endoscopic ampullectomy. Am J Gastroenterol. 2005;100: 2379-2381.

4. José Celso Ardengh, Rafael Kemp, Éder Rios Lima-Filho, José Sebastião dos Santos. Endoscopic papillectomy: The limits of the indication, technique and results. World J Gastrointest Endosc .2015 August 10;7(10):987-994.

5. Hiromitsu S, Naoteru M, Shigenari H, Hajime H, Yoshiyuki Y, Yuji $\mathrm{N}$, et al. Ampullary Adenoma Treated by Endoscopic Double-Snare Retracting Papillectomy. Gut Liver. September 2015:9(5):689-692.

6. Jong HM, Hyun JC, Yun NL. Current Status of Endoscopic Papillectomy for Ampullary Tumors. Gut Liver. November 2014;8(6):598604. 
7. Shujiro T, Takao I, Atsushi S, Shuntaro M, Ryosuke T, Fuminori M. Tips and tricks in endoscopic papillectomy of ampullary tumors: single center experience with large case series (with videos). J Hepatobiliary Pancreat Sci. 2015;22:E22-E27.

8. Dong-Won A, Ji Kon R, Jaihwan K, Won Jae Y, Sang Hyub L, Yong Tae K, et al. Endoscopic Papillectomy for Benign Ampullary Neoplasms: How Can Treatment Outcome Be Predicted? Gut Liver. March 2013;7(2):239-245.

9. Hiromitsu S, Naoteru M, Shigenari H, Hajime H, YoshiyukI Y, Yuji $\mathrm{N}$, et al. Ampullary Adenoma Treated by Endoscopic Double-Snare Retracting Papillectomy. Gut Liver. September 2015;9(5):689-692.

10. Stacy B M, Philip S, Hyungjin M K, Grace H E. A survey of ampullectomy practices.World J Gastroenterol. 2009 Jul 28;15(28):3486-3492.

11. Song J, Liu H, Li Z, Yang C, Sun Y, Wang C. Long-term prognosis of surgical treatment for early ampullary cancers and implications for local ampullectomy. BMC Surgery. 2015;15:32. 